\title{
KEPUTUSAN PEMBELIAN PRODUK KOSMETIK WARDAH PADA MAHASISWI UNIVERSITAS SURYAKANCANA DAN FAKTOR-FAKTOR YANG MEMPENGARUHINYA
}

\author{
Kasmiri \\ Perbankan Syariah, Universitas Suryakancana Cianjur \\ kasmiricampaka105@gmail.com \\ Dini Tri Setiany \\ Ekonomi Syariah, Universitas Suryakancana Cianjur \\ dinitsetiany11@gmail.com
}

\begin{abstract}
This article is written on the rapid development of the cosmetics industry in Indonesia. Not only local products but products with international brands also market their products in the Indonesian market. The local product that dominates the market share is Wardah Cosmetics, with an image of halal cosmetics, $W$ ardah cosmetics, which are in great demand. This study will focus on consumer purchasing decisions and the factors that influence it, namely product quality and price. The research was conducted in the scope of Suryakancana University students with a sample of 83 respondents, where the sample selection was using a random sampling method. Based on data analysis using multiple linear regression analysis. The findings in the article after statistical testing are partially found that product quality and price levels have a significant effect on Wardah cosmetic product purchasing decisions. Then, the two factors studied together (simultaneously) also bave a significant effect on purchasing decisions $W$ ardah cosmetic products with a contribution of $53.8 \%$ influence.
\end{abstract}

\section{Keywords: Product Quality, Price, Purchase Decision}

\begin{abstract}
Abstrak
Artikel ini ditulis atas perkembangan yang sangat pesat pada industri kosmetik di Indonesia. Tidak hanya produk lokal, produk-produk dengan brand internasional pun turut memasarkan produknya di pasar Indonesia. Produk lokal yang menguasai pangsa pasar adalah Kosmetik Wardah, dengan image sebagai kosmetik halal, produk kosmetik Wardah banyak diminati. Penelitian ini akan berfokus pada keputusan pembelian konsumen dan faktor-faktor yang mempengaruhinya yaitu kualitas produk dan harga. Penelitian dilakukan dilingkup Mahasiswi Universitas Suryakancana dengan sampel yang menjadi responden sebanyak 83 mahasiswi, dimana pemilihan sampel dengan metode random sampling. Based analisis data menggunakan analisis regresi linear berganda. Temuan pada artikel setelah pengujian statistik ini ialah secara parsial ditemukan kualitas produk dan tingkat harga berpengaruh signifikan terhadap keputusan pembelian produk kosmetik Wardah. Kemudian, kedua faktor yang diteliti secara bersama-sama (simultan) juga berpengaruh signifikan terhadap keputusan pembelian produk kosmetik wardah dengan kontribusi pengaruh 53,8\%.
\end{abstract}

Kata kunci: Kualitas Produk, Harga, Keputusan Pembeliaan 


\section{Pendahuluan}

Zaman sekarang ini, industri kosmetik di Indonesia telah berkembang pesat. Berbagai produk kosmetik dari produsen dengan berbagai merek ditawarkan kepada para konsumen. Kondisi pasar kosmetik saat ini merupakan pasar pembeli (buyer's market), artinya pembeli menempati posisi yang menentukan dalam memutuskan membeli atau tidaknya suatu produk kosmetik.

Bagi sebagian perempuan, kosmetik menjadi kebutuhan dasar yang penting. Selain untuk mempercantik diri pada acara dan tempat tertentu, kosmetik juga dijadikan sarana bagi perempuan untuk mempertegas identitas dirinya di mata masyarakat. Maka dari itu, kosmetik menjadi komoditi penting dalam market circle Indonesia.

Dalam kondisi pasar pembeli (buyer's market), para konsumen mendapat penawaran produk kosmetik dari berbagai merek, kualitas dan harga, dari perusahaan kosmetik yang bersaing agar mendapatkan pembeli potensial yang ingin membeli produk mereka. Brand lokal terbesar yang mampu menguasai pangsa pasar kosmetik di Indonesia, juga telah mendapatkan perhatian khusus dari pasar internasional adalah Wardah Kosmetik. Tidak hanya mampu menguasai pasar sebagai produk lokal, Wardah juga mampu menyaingi brand-brand Internasional seperti Make Over, Maybellin, dan produk lokal serupa seperti Emina dan Pixy.

Dengan langkah promosi yang intensif dan massif, Wardah telah memposisikan berbagai jenis produknya yang cocok untuk memenuhi kebutuhan kosmetik semua kalangan. Mengamati aktivitas promosi yang dilakukan dan tema yang diusung dalam promosi produk Wardah, tampak jaminan kualitas produk sangat ditonjolkan. Kualitas produk ini ditunjukkan dengan keterbukaan informasi jaminan produk halal, informasi keamanan produk, dan komposisi yang seimbang sehingga Wardah memberikan klaim sebagai produk yang cocok dalam mempercantik dan merawat wajah penggunanya. Dengan tema inti promosi produk dari sisi kualitas beserta manfaat produk bagi para konsumen, maka akan menjadi strategi yang ampuh dalam memenangkan persaingan pada kondisi pasar produk kosmetik Indonesia saat ini yang merupakan pasar pembeli (Buyer's Market).

Kondisi persaingan membuat produsen harus melakukan strategi pemasaran guna mendapatkan konsumen. Dikemukakan oleh (Kotler \& Amstrong, Prinsip-prinsip Pemasaran, 2008) untuk dapat mengalahkan pesaing salah satu senjata utama yang perlu dimiliki adalah kualitas produk. Jika suatu perusahaan memiliki kualitas produk yang baik, maka produknya akan tumbuh pesat dengan siklus hidup produk yang lebih lama. Lalu kemungkinan besar konsumen akan kembali membeli produk tersebut. Agar kualitas suatu produk bisa diketahui oleh konsumen, maka dari itu perusahaan harus mencantumkan manfaat mengenai produk dan cara penggunaannya.

Di samping kualitas produk, faktor harga merupakan unsur bauran pemasaran (marketing mix) yang penting. Harga produk yang ditetapkan produsen akan berdampak pada respon pasar terhadap produk yang bersangkutan. Maka, penetapan harga harus cermat dan tepat, sama dengan potensi daya beli pasar sasaran, sebagaimana yang telah diidentifikasi oleh produsen melalui analisis STP (Segmenting-Targeting- Positioning).

Strategi harga produk yang tepat akan memberikan manfaat yang baik bagi perusahaan seperti, konsumen akan lebih tertarik pada produk kita dibandingkan pesaing, keinginan konsumen untuk membeli tinggi karena harga dirasa cocok, dan dapat memberikan respon positif pada pasar secara keseluruhan.

Merek Wardah, merupakan salah satu merek dagang yang berhasil menciptakan kualitas produk dengan grade tinggi namun dengan harga yang tepat. Mengedepankan kualitas yang 
bagus sehingga mampu merawat kulit dengan baik, selain itu wardah juga memiliki klusterkluster pengguna yang memang nyaman dengan produknya. Dengan kata lain, Wardah mampu menentukan segmentasi pasarnya dengan baik. Maka dari itu, dalam pasar nasional Wardah sudah menjadi pesaing bagi merek dagang kosmetik lainnya.

Salah satu konsumen Wardah adalah mahasiswi Universitas Suryakancana, disimpulkan bahwa sebagian besar mahasiswi Universitas Suryakancana memandang bahwa kosmetik wardah merupakan produk kosmetik yang berkualitas dan memandang label halal identik dengan produk kosmetik merek Wardah. Dari hasil observasi itupun tergali informasi bahwa penjualan produk kosmetik merek Wardah semakin meningkat, hal ini terindikasi dengan makin banyak dan tersebarnya counter-counter Wardah di Cianjur. Oleh karena itu penulis tertarik untuk meneliti sejauh mana kualitas produk dan harga yang ada pada Wardah dapat mempengaruhi keputusan pembelian produk tersebut

\section{Metode}

Pada artikel kali ini, metodologi yang digunakan ialah jenis penelitian kuantitatif, metode deskriptif dengan pendekatan explanatory survey. Penelitian kuantitatif biasanya berupa penelitian survey yang menjelaskan hubungan antara variable bebas dengan variable terikat yaitu kualitas produk dan tingkat harga terhadap keputusan pembelian. Data-data variabel yang digunakan dalam artikel kali ini berasal dari responden kuesioner dimana menggunakan skala likert dan dokumentasi berupa studi kepustakaan. Populasi dalam penelitian ini ialah Mahsiswi Universitas Suryakancana. Dikarenakan jumlahnya terlalu banyak, maka sumber data penelitian ditentukan berdasarkan sampel, teknik sampel random sampling dan dengan menggunakan rumus slovin di peroleh sampel sebanyak 83 orang. Teknis analisis data yang di pakai sebagai based ialah analisis regresi berganda, kemudian dilakukan pengujian instrumen penelitian.

\section{Hasil dan Pembahasan}

\subsection{Demografi Responden}

Rincian responden sampel penelitian, dapat ditelaah dalam table berikut ini:

Tabel 1 Karakteristik Responden berdasarkan Usia

\begin{tabular}{|l|c|c|}
\hline \multicolumn{1}{|c|}{ Usia } & Frekuensi & Presentasi \\
\hline $18-20$ tahun & 12 & $14,5 \%$ \\
\hline $21-25$ tahun & 71 & $85,5 \%$ \\
\hline Jumlah & $\mathbf{8 3}$ & $\mathbf{1 0 0} \%$ \\
\hline
\end{tabular}

Sumber: Data Primer diolah oleh peneliti

Tabel 2 Karakteristik Responden berdasarkan Fakultas

\begin{tabular}{|c|c|c|}
\hline Fakultas & Frekuensi & Persentasi \\
\hline Hukum & 11 & $13,3 \%$ \\
\hline FKIP & 26 & $31,3 \%$ \\
\hline Faster & 3 & $3,6 \%$ \\
\hline FEBI & 41 & $49,4 \%$ \\
\hline Teknik & 2 & $2,4 \%$ \\
\hline Jumlah & $\mathbf{8 3}$ & $\mathbf{1 0 0} \%$ \\
\hline
\end{tabular}

Sumber: Data Primer diolah oleh peneliti 
Tabel 3 Karakteristik Responden berdasarkan Semester Kuliah

\begin{tabular}{|c|c|c|}
\hline Semester & Frekuensi & $\mathbf{( \% )}$ \\
\hline II & 2 & 2,4 \\
\hline IV & 25 & 30,1 \\
\hline VI & 17 & 20,5 \\
\hline VIII & 39 & 47 \\
\hline Jumlah & $\mathbf{8 3}$ & $\mathbf{1 0 0}$ \\
\hline
\end{tabular}

Sumber: Data Primer diolah oleh peneliti

Selanjutnya, berdasarkan data rekapitulasi keseluruhan respon (tanggapan) responden terhadap variabel kualitas produk, menunjukkan bahwa sebagian besar responden (48,18\%) menyatakan setuju mengenai pentingnya sebuah kualitas produk kosmetik bagi mereka. Oleh karena itu dari hasil sementara tanggapan responden yang dilihat dari jumlah persentase, kualitas produk pada kosmetik Wardah memiliki hubungan pengaruh positif dengan peningkatan keputusan pembelian. Temuan lain dari peneltian, berdasarkan data rekapitulasi keseluruhan respon (tanggapan) responden terhadap variabel harga, menunjukkan bahwa sebagian besar responden (53,01\%) menyatakan setuju mengenai pentingnya faktor harga dalam memutuskan untuk membeli produk wardah. Dengan demikian tingkat harga memiliki pengaruh terhadap keputusan pembelian. Dari rekapitulasi data (tanggapan) responden terhadap keputusan pembelian tersebut, memperlihatkan bahwa sebagian besar responden $(46,16 \%)$ setuju bahwa keputusan pembelian para mahasiswi Universitas Suryakancana terhadap produk kosmetik Wardah dipengaruhi oleh variabel kualitas produk dan variabel harga.

\subsection{Uji Instrumen Penelitian}

Uji validitas variabel kualitas produk, data menunjukkan bahwa seluruh instrumen yang digunakan dalam pengukuran kualitas produk dinyatakan valid dengan $\mathrm{r}$ tabel 0,230 dimana ketentuannya $\mathrm{r}$ hitung $>\mathrm{r}$ tabel dengan sig $<0,05$.

Tabel 4 Uji Validitas Kualitas Produk

\begin{tabular}{|c|c|c|c|c|c|c|}
\hline No & $\begin{array}{c}\text { Butiran dalam } \\
\text { Kuesioner }\end{array}$ & r-hitung & $\begin{array}{c}\text { Nilai kritis } \\
\text { (r-tabel) }\end{array}$ & $\begin{array}{c}\text { Sig. } \\
\mathbf{2 t a i l e d} \\
\mathbf{( p - l e v e l )}\end{array}$ & $\begin{array}{c}\text { Taraf Sig. } \\
\boldsymbol{\alpha}=\mathbf{0 , 0 5}\end{array}$ & Ket. \\
\hline 1 & P.1 & 0,704 & 0,230 & 0,000 & 0,05 & Valid \\
\hline 2 & P.2 & 0,574 & 0,230 & 0,000 & 0,05 & Valid \\
\hline 3 & P.3 & 0,687 & 0,230 & 0,000 & 0,05 & Valid \\
\hline 4 & P.4 & 0,574 & 0,230 & 0,000 & 0,05 & Valid \\
\hline 5 & P.5 & 0,685 & 0,230 & 0,000 & 0,05 & Valid \\
\hline 6 & P.6 & 0,687 & 0,230 & 0,000 & 0,05 & Valid \\
\hline 7 & P.7 & 0,630 & 0,230 & 0,000 & 0,05 & Valid \\
\hline 8 & P.8 & 0,506 & 0,230 & 0,000 & 0,05 & Valid \\
\hline 9 & P.9 & 0,612 & 0,230 & 0,000 & 0,05 & Valid \\
\hline 10 & P.10 & 0,506 & 0,230 & 0,000 & 0,05 & Valid \\
\hline 11 & P.11 & 0,680 & 0,230 & 0,000 & 0,05 & Valid \\
\hline 12 & P.12 & 0,656 & 0,230 & 0,000 & 0,05 & Valid \\
\hline
\end{tabular}

Sumber: Output IBM SPSS Ver.24.0, data diolah 
Keputusan Pembelian Produk Kosmetik Wardah pada Mahasiswa Universitas...

Sedangkan untuk realibilitas, ketentuan cronbach alpha yang lolos uji reliabilitas adalah > 0,60. Berikut hasil uji SPSS yang didapatkan:

Tabel 5 Uji Reliabilitas Kualitas Produk

\begin{tabular}{|c|c|}
\hline \multicolumn{2}{|c|}{ Reliability Statistics } \\
\hline Cronbach's Alpha & N of Items \\
\hline .899 & 12 \\
\hline
\end{tabular}

Sumber: Output IBM SPSS Ver.24.0, data diolah

Dari tabel di atas diperoleh hasil untuk uji reliabilitas instrumen pengukuran kualitas produk adalah reliabel, karena 0,899 > 0,60.

Selanjutnya uji validitas pada variabel harga, diperoleh hasil sebagai berikut:

Tabel 6 Uji Validitas Tingkat Harga

\begin{tabular}{|c|c|c|c|c|c|c|}
\hline No & $\begin{array}{c}\text { Butiran dalam } \\
\text { Kuesioner }\end{array}$ & r-hitung & $\begin{array}{c}\text { Nilai kritis } \\
\text { (r-tabel) }\end{array}$ & $\begin{array}{c}\text { Sig. } \\
\mathbf{2 t a i l e d} \\
(\mathbf{p}-\text {-level) }\end{array}$ & $\begin{array}{c}\text { Taraf Sig. } \boldsymbol{\alpha} \\
\mathbf{= 0 , 0 5}\end{array}$ & Ket. \\
\hline 1 & P.1 & 0,480 & 0,225 & 0,000 & 0,05 & Valid \\
\hline 2 & P.2 & 0,532 & 0,225 & 0,000 & 0,05 & Valid \\
\hline 3 & P.3 & 0,336 & 0,225 & 0,000 & 0,05 & Valid \\
\hline 4 & P.4 & 0,494 & 0,225 & 0,000 & 0,05 & Valid \\
\hline 5 & P.5 & 0,667 & 0,225 & 0,000 & 0,05 & Valid \\
\hline 6 & P.6 & 0,687 & 0,225 & 0,000 & 0,05 & Valid \\
\hline 7 & P.7 & 0,670 & 0,225 & 0,000 & 0,05 & Valid \\
\hline 8 & P.8 & 0,355 & 0,225 & 0,000 & 0,05 & Valid \\
\hline 9 & P.9 & 0,684 & 0,225 & 0,000 & 0,05 & Valid \\
\hline
\end{tabular}

Sumber: Output IBM SPSS Ver.24.0, data diolah

Berdasarkan hasil uji validitas instrument penelitian variabel harga ditemukan hasil seluruh instrumen penelitian yang digunakan pada variabel harga dinyatakan valid dengan ketentuan hasil $r$ hitung $>\mathrm{r}$ tabel 0,225 dan taraf sig $>0,05$. Sedang berdasarkan hasil uji reliabilitas, dari hasil tabel di bawah ini:

Tabel 7 Uji Reliabilitas Harga

\begin{tabular}{|c|c|}
\hline \multicolumn{2}{|c|}{ Reliability Statistics } \\
\hline Cronbach's Alpha & N of Items \\
\hline .835 & 9 \\
\hline
\end{tabular}

Sumber: Output IBM SPSS Ver.24.0, data diolah

Pada variabel harga, instrument penelitian variabel Harga $\left(\mathrm{X}_{2}\right)$ diperoleh nilai Alpha 0,899 , melebihi nilai $(\alpha=0,60)$. Maka dapat disimpulkan bahwa instrumen penelitian yang digunakan reliable $(0,835>0,60)$.

Selanjutnya, uji validitas pada keputusan pembelian, diperoleh hasil yang sama yaitu valid untuk seluruh instrumen pertanyaan yang digunakan dalam penelitian ini. Berikut hasil datanya:

Tabel 8 Uji Validitas Keputusan Pembelian

\begin{tabular}{|c|c|c|c|c|c|c|}
\hline No & $\begin{array}{c}\text { Butiran dalam } \\
\text { Kuesioner }\end{array}$ & r-hitung & $\begin{array}{c}\text { Nilai kritis } \\
(\mathbf{r} \text {-tabel) }\end{array}$ & $\begin{array}{c}\text { Sig. } \\
\mathbf{2 t a i l e d} \\
(\mathbf{p} \text {-level) }\end{array}$ & $\begin{array}{c}\text { Taraf Sig. } \boldsymbol{\alpha} \\
\mathbf{= 0 , 0 5}\end{array}$ & Ket. \\
\hline 1 & P.1 & 0,806 & 0,227 & 0,000 & 0,05 & Valid \\
\hline 2 & P.2 & 0,611 & 0,227 & 0,000 & 0,05 & Valid \\
\hline
\end{tabular}




\begin{tabular}{|c|c|c|c|c|c|c|}
\hline 3 & P.3 & 0,661 & 0,227 & 0,000 & 0,05 & Valid \\
\hline 4 & P.4 & 0,456 & 0,227 & 0,000 & 0,05 & Valid \\
\hline 5 & P.5 & 0,661 & 0,227 & 0,000 & 0,05 & Valid \\
\hline 6 & P.6 & 0,748 & 0,227 & 0,000 & 0,05 & Valid \\
\hline 7 & P.7 & 0,806 & 0,227 & 0,000 & 0,05 & Valid \\
\hline 8 & P.8 & 0,796 & 0,227 & 0,000 & 0,05 & Valid \\
\hline 9 & P.9 & 0,772 & 0,227 & 0,000 & 0,05 & Valid \\
\hline 10 & P.10 & 0,456 & 0,227 & 0,000 & 0,05 & Valid \\
\hline
\end{tabular}

Sumber: Output IBM SPSS Ver.24.0, data diolah

Merujuk pada tabel, uji validitas dinyatakan valid karena $\mathrm{r}$ hitung pada seluruh item pertanyaan keputusan pembelian lebih besar daripada $r$ tabel 0,227, dan signifikansi lebih kecil dari 0,05 .

Kemudian hasil uji reliabilitas pada keputusan pembelian adalah sebagai berikut:

\section{Tabel 9 Uji Reliabilitas Keputusan Pembelian}

\section{Reliability Statistics}

\begin{tabular}{|c|c|}
\hline Cronbach's Alpha & N of Items \\
\hline .912 & 10 \\
\hline
\end{tabular}

Sumber: Output IBM SPSS Ver.24.0, data diolah

Hasil uji reliabilitas didapatkan Cronbach Alpha 0,912 artinya ini lebih besar dari ketentuan 0,60. Maka, seluruh item pertanyaan pada keputusan pembelian dinyatakan reliebel.

\subsection{Statistik Deskriptif}

Statistik deskriptif digunakan untuk menunjukkan karakteristik suatu variabel, diman dalam hasil perhitungan terdapat mean (nilai rata-rata) dari hasil yang diperoleh, nilai minimum dari hasil yang diperoleh, nilai maksimum dari hasil yang diperoleh dari variabel, dan standar deviasi adalah simpangan baku dari setiap variabel. Berikut hasil statistik deskriptif yang diperoleh berdasarkan perhitungan menggunakan software SPSS:

Tabel 10 Statistik Deskriptif

Descriptive Statistics

\begin{tabular}{|c|c|c|c|c|c|c|c|c|c|}
\hline & $\mathrm{N}$ & Range & $\begin{array}{c}\text { Minimu } \\
\mathrm{m}\end{array}$ & $\begin{array}{c}\text { Maximu } \\
\mathrm{m}\end{array}$ & Sum & \multicolumn{2}{|c|}{ Mean } & $\begin{array}{c}\text { Std. } \\
\text { Deviatio } \\
\mathrm{n}\end{array}$ & $\begin{array}{c}\text { Varianc } \\
\mathrm{e}\end{array}$ \\
\cline { 2 - 9 } & Statistic & Statistic & Statistic & Statistic & Statistic & $\begin{array}{c}\text { Statisti } \\
\mathrm{c}\end{array}$ & $\begin{array}{c}\text { Std. } \\
\text { Erro } \\
\mathrm{r}\end{array}$ & $\begin{array}{c}\text { Statistic } \\
\text { Statistic }\end{array}$ \\
\hline $\begin{array}{c}\text { Kualitas } \\
\text { Produk }\end{array}$ & 83 & 26 & 34 & 60 & 3758 & 45.28 & .650 & 5.921 & 35.056 \\
\hline $\begin{array}{c}\text { Harga } \\
\text { Keputus } \\
\text { an } \\
\begin{array}{c}\text { Pembeli } \\
\text { an }\end{array}\end{array}$ & 83 & 19 & 22 & 41 & 2758 & 33.23 & .370 & 3.369 & 11.349 \\
\hline $\begin{array}{c}\text { Valid N } \\
\text { (listwise } \\
\text { ) }\end{array}$ & 83 & 36 & 14 & 50 & 2839 & 34.20 & .698 & 6.357 & 40.409 \\
\hline
\end{tabular}

Sumber: Output IBM SPSS Ver.24.0 


\subsection{Analisis Pengaruh Kualitas Produk terhadap Keputusan Pembelian Produk Kosmetik Wardah}

Kotler dan Amstrong menyatakan bahwa salah satu yang menjadi sarana positioning utama pasar adalah kualitas produk. Kualitas ini memiliki korelasi yang erat dengan pelanggan, karena dampaknya langsung pada kinerja produk dan jasa dan implikasinya pada pelanggan. Dengan kata lain, kualitas produk yang baik adalah tidak adanya kerusakan pada produk tersebut (Kotler \& Amstrong, Prinsip-Prinsip Manajemen , 2006). Fungsi suatu kualitas produk ialah produk memiliki ha-hal berikut kehandalan, keawetan, kemudahan, penggunaan dan perbaikan, serta berbagai fungsi lainnya (Nasution, 2005).

Kualitas produk menurut Tjiptono ialah tingkat mutu yang diinginkan dan pengendalian keseragaman untuk mencapai kualitas atau mutu tersebut dalam memenuhi kebutuhan konsumen. Menurutnya, untuk menguasai pasar diperlukan kualitas produk yang baik. Lalu bagi masyarakat, kualitas produk untuk mengukur kepuasannya dalam memutuskan pembelian (Tjiptono, 2008).

Dimensi dan pengukuran kualitas produk dalam (Nasution, 2005) disebutkan ada delapan kriteria, yaitu (1) Performa, dimensi ini berkaitan dengan aspek fungsional suatu produk; (2) Keistimewaan, dimensi ini merupakan pilihan-pilihan dan pengembangan dari performa; (3) Kehandalan, dimensi ini berkaitan dengan kemungkinan keberhasilan produk berhasil dalam peride tertentu; (4) Kesesuaian dengan spesifikasi, ini kaitainnya dengan spesifikasi awal berdasarkan keinginan konsumen; (5) Daya tahan, adalah masa pakai suatu produk; (6) Kemampuan pelayanan, kaitannya dengan kecepatan, kemudahan, akurasi, dan keunggulan; (7) Estetika, berkaitan dengan keindahan namun ini bersifat subjektif; dan (8) Kualitas yang diinginkan, berikaitan dengan perasaan konsumen.

Kualitas produk memiliki korelasi yang kuat dengan keputusan pembelian calon konsumen. Menurut Kotler dan Amstrong, kualitas produk yang baik cenderung meningkatkan insting keputusan untuk membeli suatu produk. Kemudian, para konsumen akan merekomendasikan produk tersebut pada teman-temannya. Jadi kualitas produk memiliki hubungan yang positif dimana kualitas produk yang baik akan meningkatkan insting keputusan pembelian konsumen (Kotler \& Amstrong, Prinsip-prinsip Pemasaran,, 2008). Dengan kata lain, ketika kualitas produk yang dihasilkan baik maka persepsi konsumen pada kualitas produk akan tinggi dan berdampak pada keputusan pembelian yang tinggi.

Untuk membuktikan teori di atas, dilakukan perhitungan dengan hasil berikut ini:

Tabel 11 Uji $t$ Kualitas Produk terhadap Keputusan Pembelian

\begin{tabular}{|c|c|c|c|c|c|c|}
\hline \multicolumn{7}{|c|}{ Coefficients $^{a}$} \\
\hline & \multirow[t]{2}{*}{ Model } & \multicolumn{2}{|c|}{ Unstandardized Coefficients } & $\begin{array}{l}\text { Standardized } \\
\text { Coefficients }\end{array}$ & \multirow[t]{2}{*}{$\mathrm{T}$} & \multirow[t]{2}{*}{ Sig. } \\
\hline & & $\mathrm{B}$ & Std. Error & Beta & & \\
\hline \multirow{3}{*}{1} & (Constant) & -6.961 & 4.862 & & -1.432 & .156 \\
\hline & Kualitas Produk & .635 & .106 & .592 & 6.008 & .000 \\
\hline & Harga & .373 & .186 & .198 & 2.006 & .048 \\
\hline
\end{tabular}

a. Dependent Variable: Keputusan Pembelian

Sumber: Output IBM SPSS Ver.24.0

Penelitian ini menggunakan based uji regresi linear berganda. Hasil diatas dapat interpretasikan bahwa kualitas produk memiliki pengaruh yang signifikan terhadap keputusan pembelian produk kosmetik wardah pada mahasiswi Universitas Suryakancana. Hal ini ditunjukkan dengan $\mathrm{t}$ hitung $>\mathrm{t}$ tabel yaitu $6,008>1,989$, dan taraf signifikansi $0.000<0,05$. 
Kemudian, kotribusi atau pengaruh variabel kualitas produk terhadap keputusan pembelian sebesar 42,5\%, penghitungannya menggunakan Sumbangan Efektif (SE) yaitu SE (X) \%= $\operatorname{Beta}_{\mathrm{x}} \mathrm{X} \mathrm{r}_{\mathrm{xy}} \mathrm{X} 100 \%$

Hasil penelitian yang diperoleh ini, ternyata konsisten dengan penelitian sebelumnya yaitu (Kartika, 2019) dimana penelitian dilakukan pada objek smartphone Oppo dan didapatkan hasil kualitas produk berpengaruh siginifikan terhadap keputusan pembelian dengan 7,454 > 1,9844. Selain itu juga penelitian milik (Putri, 2016) dimana hasilnya adalah kualitas produk berpengaruh signifikan terhadap keputusan pembelian kosmetik Wardah. Dan penelitian (Habibah \& Sumiati, 2016) yang juga memiliki objek sama menunjukkan hasil kualitas produk juga mempengaruhi secara signifikan terhadap keputusan pembelian.

Pada gilirannya, peneliti menemukan bahwa kualitas produk menjadi indikator utama dalam pembeelian suatu produk, salah satunya produk Wardah. Teori, hasil penelitian dan penelitian terdahulu membuktikan bahwa kualitas produk berimplikasi positif terhadap keputusan pembelian. Maka teori ini juga berlaku, bahwa keputusan pembelian produk kosmetik Wardah pada Mahasiswi Universitas Suryakancana dipengaruhi oleh kualitas produk.

\subsection{Analisis Pengaruh Harga terhadap Keputusan Pembelian Produk Kosmetik Wardah}

Untuk mendapatkan keuntungan dan manfaat atas suatu produk atau jasa, maka calon konsumen harus memberikan bayaran berupa sejumlah uang atasnya hal ini disebut harga. Kemudian, pendapat lain menyatakan bahwa harga adalah sebuah pengorbanan yang dikeluarkan dengan mengeluarkan sejumlah uang untuk medapatkan gabungan sebuah produk atau layanan yang diinginkan (Laksana, 2008). Selanjutnya, harga juga dapat diartikan sebagai sesuatu yang dibayarkan dalam bentuk mata uang oleh konsumen untuk membeli atau menikmati barang atau jasa yang ditawarkan.

Indikator dalam pengukuran harga pada penelitian ini merujuk pada indikator yang dicetuskan oleh Stanton dalam (Anggraini , Hidayat, \& Sunarti, 2019), menurutnya ada empat indikator yaitu (1) Keterjangkauan harga; (2) Kesesuaian harga dengan kualitas produk; (3) Daya saing harga; dan (4) Kesesuaian harga dengan manfaat.

Harga ini dapat menjadi tolak ukur bagi calon konsumen untuk menentukan pilihan membeli atau tidak suatu produk. Karena ketika mendengar harga, calon pembeli akan membandingkannya dengan kualitas, manfaat atau dengan produk serupa yang mungkin lebih murah tapi memiliki manfaat yang sama. Oleh karena itu, diperlukan kebijakan penetapan harga yang sesuai dengan konsumen, namun juga memberikan keuntungan bagi perusahaan.

Berikut hasil perhitungan menggunakan software SPSS untuk melihat pengaruh atau tidaknya:

Tabel 12 Uji $t$ Harga terhadap Keputusan Pembelian Coefficients $^{a}$

\begin{tabular}{|c|c|c|c|c|c|c|}
\hline \multirow{2}{*}{ Model } & \multicolumn{2}{|c|}{ Unstandardized Coefficients } & $\begin{array}{c}\text { Standardized } \\
\text { Coefficients }\end{array}$ & \multirow{2}{*}{ T } & \multirow{2}{*}{ Sig. } \\
\cline { 2 - 5 } \multicolumn{2}{|c|}{} & B & Std. Error & Beta & & \\
\hline \multirow{3}{*}{1} & (Constant) & -6.961 & 4.862 & & -1.432 & .156 \\
\cline { 2 - 7 } & Kualitas Produk & .635 & .106 & .592 & 6.008 & .000 \\
\cline { 2 - 7 } & Harga & .373 & .186 & .198 & 2.006 & .048 \\
\hline
\end{tabular}

a. Dependent Variable: Keputusan Pembelian

Sumber: Output IBM SPSS Ver.24.0 
Penelitian ini menggunakan based uji regresi linear berganda. Hasil diatas dapat interpretasikan bahwa harga memiliki pengaruh yang signifikan terhadap keputusan pembelian produk kosmetik wardah pada mahasiswi Universitas Suryakancana. Hal ini ditunjukkan dengan t hitung $>$ t tabel yaitu 2,006 $>1,989$, dan taraf signifikansi $0.048<0,05$. Kemudian, kotribusi atau pengaruh variabel kualitas produk terhadap keputusan pembelian sebesar 11,3\%, penghitungannya menggunakan Sumbangan Efektif (SE) yaitu SE (X) \% = Beta X $\mathrm{r}_{\mathrm{xy}} \mathrm{X} 100 \%$.

Hasil penelitian yang diperoleh ini, ternyata konsisten dengan penelitian sebelumnya yaitu (Anggraini, Hidayat, \& Sunarti, 2019) dengan hasil penelitian harga mempengaruhi keputusan pembeli dalam memberi produk kosmetik Wardah. Kemudian skripsi milik (Ardyani, 2019), dalam penelitiannya diketahui bahwa harga mempunyai pengaruh parsial terhadap keputusan pembelian lipstik Wardah. Dan penelitian (Habibah \& Sumiati, 2016) yang juga memiliki objek sama menunjukkan hasil harga juga mempengaruhi secara signifikan terhadap keputusan pembelian.

Merujuk pada teori, hasil penelitian, dan penelitian terdahulu bahwa terbukti bahwa harga memiliki dampak positif terhadap keputusan pembelian suatu produk, termasuk produk kosmetik wardah. Oleh sebab itu, perusahaan memerlukan strategi yang terpat dalam penentuan harga, agar tidak kalah dari pesaing dengan produk sejenis. Menurut hemat peneliti, harga yang tepat adalah berbanding lurus dengan kualitas produk, maka ketika sesuai persepsi calon konsumen akan terbentuk untuk memutuskan pembeliaan. Penelitian ini menemukan hasil akhir bahwa, keputusan pembelian produk kosmetik wardah pada Mahasiwi Universitas Suryakancana dipengaruhi oleh harga.

\subsection{Analisis Pengaruh Kualitas Produk dan Harga terhadap Keputusan Pembelian Produk Kosmetik Wardah}

Keputusan merupakan keadaan di mana seseorang harus memilih untuk melakukan sesuatu. Keputusan tersebut berasal dari dorongan dalam diri seseorang, namun juga diinisiasi oleh faktor dari luar diri. Pembelian berarti seseorang mengkonsumsi sesuatu yang mendapatkannya ada pengorbanan. Maka keputusan pembelian adalah aktivitas konsumen yang menciptakan reference merek-merek dalam suatu pilihan kemudian memutuskan benar-benar membeli satu merek yang benar-benar disukai.

Keputusan pembelian terjadi saat konsumen mengenali masalahnya, kemudian mencari informasi mengenai produk tertentu, dan memikirkan, mengevaluasi satu persatu apakah produk tersebut dapat memecahkan masalah mereka, setelah mendapat menjawab maka itu akan mengarah pada keputusan pembelian (Tjiptono, 2008). Dimensi yang digunakan dalam mengukur keputusan pembelian terdiri pilihan atas produk yang ingin dibeli, merek yang tertera, distributor, kuantitas pembelian, waktu pembelian, dan metode pembayaran (Kotler \& Keller, 2012).

Dapat disimpulkan bahwa semakin baik persepsi harga konsumen akan sebuah harga maka keputusan pembelian pun semakin meningkat tetapi sebaliknya jika persepsi konsumen buruk akan harga suatu produk maka keputusan pembelian pun akan semakin menurun

\section{Tabel 13 Uji F}

ANOVA $^{a}$

\begin{tabular}{|c|c|c|c|c|c|c|}
\hline \multicolumn{2}{|l|}{ Model } & Sum of Squares & Df & Mean Square & F & Sig. \\
\hline \multirow{3}{*}{1} & Regression & 1784.131 & 2 & 892.065 & 46.663 & $.000^{\mathrm{b}}$ \\
& ResidualTotal & 1529.387 & 80 & 19.117 & & \\
& & 3313.518 & 82 & & & \\
\hline
\end{tabular}

a. Dependent Variable: Keputusan Pembelian

b. Predictors: (Constant), Harga, Kualitas Produk

Sumber: Output IBM SPSS Ver.24.0 
Selanjutnya, dari hasil pengujian simultan (uji F) pada variabel Kualitas Produk dan Harga diperoleh nilai $\mathrm{F}$ hitung sebesar 46,663 dengan nilai signifikansi sebesar 0,000. Hasil tersebut menunjukkan bahwa nilai $F$ hitung lebih besar daripada $F$ tabel $(46,663>3,111)$ dan nilai signifikansi lebih kecil daripada 0,05 $(0,000<0,05)$. Dengan demikian, dapat disimpulkan bahwa terdapat pengaruh signifikan dari variabel Kualitas Produk dan Harga secara bersamasama terhadap Keputusan Pembelian.

Selanjutnya kekuatan hubungan dan kontribusi pengaruh secara bersamaan antara kualitas produk dan harga dapat dilihat dari hasil berikut ini:

Tabel 14 Uji Koefisien Determinasi Model Summary ${ }^{b}$

\begin{tabular}{|r|c|c|c|c|c|}
\hline Model & $\mathrm{R}$ & R Square & $\begin{array}{c}\text { Adjusted R } \\
\text { Square }\end{array}$ & $\begin{array}{c}\text { Std. Error of the } \\
\text { Estimate }\end{array}$ & Durbin-Watson \\
\hline 1 & $.734^{\mathrm{a}}$ & .538 & .527 & 4.372 & 1.748 \\
\hline
\end{tabular}

a. Predictors: (Constant), Harga, Kualitas Produk

b. Dependent Variable: Keputusan Pembelian

Sumber: Output IBM SPSS Ver.24.0

Berdasarkan koefisisen determinasi $\left(\mathrm{R}^{2}\right)$ besarnya pengaruh dari variabel product of quality dan price terhadap purchase intention adalah 53,8\% dan sisanya 46,2\% dipengaruhi oleh faktor lain diluar yang diteliti dalam penelitian ini. Faktor tersebut diantara, citra merek, brand image, promosi, minat beli, lokasi, kelengkapan informasi produk, budaya, dan pengetahuan.

Temua akhir pada bagian ini adalah, keputusan pembelian produk kosmetik Wardah pada mahasiswa Universitas Suryakancana dipengaruhi oleh faktor kualitas produk dan harga. Oleh karena itu, secara tgerus menerus pemasar harus memperhatikan kualitas produk yang ditawarkan. Kelalian dalam memperhatikan kualitas produk akan berdampak pada penurunan loyalitas konsumen sehingga akan menurunkan transaksi dan omzet penjualan produk. Apabila marketer menunjukkan kualitas produk dengan promosi yang kreatif dan inovatif, maka berapapun harga produk tersebut akan membuat calon konsumen tertarik dan memutuskan untuk membeli. Selanjutnya, penelitian ini mendukung hasil penelitian dari (Lina, 2017) yang hasil uji F nya menunjukkan keputusan pembelian dipengaruhi oleh promosi, harga, dan kualitas produk. Kemudian penelitian (Ayuniah , 2017) bahwa citra merek, promosi, iklan, harga, dan kualitas produk mempengaruhi keputusan pembelian. Terakhir, (Aisyah, 2018) yang menyatakan merujuk pada hasil uji $\mathrm{F}$ bahwa kualias produk, harga dan promosi mempengaruhi keputusan pembeliaan produk Wardah.

\section{Kesimpulan}

Penelitian mengenai keputusan pembelian pada produk kosmetik pada dasarnya sudah sering dilakukan, namun artikel ini memiliki objek yang baru yaitu mahasiswi Universitas Suryakancana. Penelitian ini memperkuat penelitian sebelumnya dan membuktikan teori-teori pakar seperti dijelaskan di atas apakah berlaku pada responden pada artikel ini. Hasil akhir menemukan bahwa, teori tersebut berlaku dan hasil penelitian pun diperkuat dengan penelitian sebelumnya. Secara parsial, keputusan pembelian produk kosmetik Wardah pada mahasiswi Universitas Suryakancana dipengaruhi oleh kualitas produk sebesar 42,5\% dan harga sebesar 11,3\%. Kemudian, ketika keduanya digabungkan keputusan pembelian produk kosmetik Wardah pada mahasiswi Universitas Suryakancana dipengaruhi oleh kualitas produk dan harga dengan pengaruh sebesar 53,8\%. 


\section{Referensi}

Aisyah, N. (2018). Pengaruh Kualitas Produk, Harga, dan Promosi terhadap Keputusan Pembelian "Produk Wardab" di Kecamatan Purwodadi Grebekan. Surakarta: Universitas Muhammadiyah Surakarta.

Anggraini , E. I., Hidayat, K., \& Sunarti. (2019). Pengaruh Kualitas Produk dan Harga terhadap Keputusan Pembeliaan (Survei pada Pembeli yang Menggunakan Produk Wardah di Counter Wardah Matahari Department Store Malang Town Square) . Jurnal Administrasi Bisnis (JAB), Vol. 73, No. 2, 118-124.

Ardyani, D. (2019). Pengaruh Kualitas Produk dan Harga terhadap Keputusan Pembelian Produk Kosmetik Lipstik Wardah (Studi Kasus Mahasiswi Fakultas Ekonomi dan Bisnis Universitas Veteran Jakarta). Jakarta: Universitas Pembangunan Nasional Veteran Jakarta .

Ayuniah , P. (2017). Analisis Pengaruh Citra Merek, Kualitas Produk, Iklan, dan Harga terhadap Keputusan Pembelian Kosmetik Wardah (Studi Kasus Pada Mahasiswa Manajemen Fakultas Ekonomi Universitas Gunadarma yang Mengambil Kuliah di Kampus Depok). Jurnal Ekonomi Bisnis, Vol. 22, No. 3, 208-219.

Habibah, U., \& Sumiati. (2016). Pengaruh Kualitas Produk dan Harga terhadap Keputusan Pembeliaan Produk Kosmetik Wardah di Kota Bangkalan Madura. Jurnal Ekonomi dan Bisnis (JEB) 27, Vol. 1, No. 1, 31-48.

Kartika, C. (2019). Pengaruh Kualitas Produk dan Harga terbadap Keputusan Pembelian Smartphone Oppo pada Mahasiswa Fisip UIN Sunan Gunung Djati Bandung. Bandung : Perpustakaan Digital UIN Sunan Gunung Djati Bandung (digilib.uinsgd.ac.id/25801/).

Kotler, P., \& Amstrong, G. (2006). Prinsip-Prinsip Manajemen . Jakarta: Erlangga.

Kotler, P., \& Amstrong, G. (2008). Prinsip-prinsip Pemasaran. Jakarta: Erlangga.

Kotler, P., \& Amstrong, G. (2008). Prinsip-prinsip Pemasaran,. Jakarta: Erlangga.

Kotler, P., \& Keller, K. L. (2012). Marketing Manajemen. New Jearsey: Pearson Prentice, Inc.

Laksana, F. (2008). Manajemen Pemasaran: Pendekatan Praktis. Yogyakarta: Graha Ilmu.

Lina, R. F. (2017). Pengaruh Harga, Promosi, dan Kualitas Produk terhadap Keputusan Pembelian Produk Exclusive Matte Lip Cream pada Wardah Beauty House Medan. Medan: Repository Universitas Sumatera Utara.

Nasution, M. H. (2005). Manajemen Mutu Terpadu: Total Quality Manajemen,. Bogor: Ghalia Indonesia.

Putri, E. K. (2016). Analisis Pengaruh Harga, Kualitas Produk, dan Iklan terhadap Keputusan Pembeliaan Kosmetik Wardah. Surakarta: Universitas Muhammadiyah Surakarta.

Tjiptono, F. (2008). Strategi Pemasaran. Yogyakarta : Penerbit Andi. 